\title{
Agent based modelling and energy planning - Utilization of MATSim for transport energy demand modelling
}

\author{
$\underline{\text { T. Novosel }}^{1}$, L. Perković1, M. Ban ${ }^{1}$, H. Keko ${ }^{2}$, T. Pukšec ${ }^{1}$, G. Krajačić1 ${ }^{\text {, N. Duić }}{ }^{1}$ \\ ${ }^{1}$ University of Zagreb; Faculty of Mechanical Engineering and Naval Architecture, \\ Department of Energy, Power Engineering and Environment \\ Ivana Lučića 5; 10002 Zagreb; Croatia \\ ${ }^{2}$ Energy Institute Hrvoje Požar, Department for Energy Generation and Transformation \\ Savska 163, 10001 Zagreb, Croatia \\ tomislav.novosel@fsb.hr
}

The transportation sector is one of the major energy consumers in most energy systems and a large portion of the energy demand is linked to road transport and personal vehicles. It accounted for $32.8 \%$ of the final energy consumption of Croatia in 2011 making it the second most energy demanding sector. Because of their higher efficiency, a modal switch from conventional internal combustion engines (ICE) to electric vehicles (EVs) has the potential to greatly reduce the overall energy demand of the transport sector. Our previous work has shown that a transition to EVs in a combination with a modal split from air and road to rail transport can reduce the energy consumption in Croatia by $99 \mathrm{PJ}$, which is approximately $59 \%$, by the year 2050 when compared to the business as usual scenario. The goal of this paper is to model the hourly distribution of the energy consumption of EVs and use the calculated load curves to test their impact on the Croatian energy system. The hourly demand for the transport sector has been calculated using the agent-based modelling tool MATSim on a simplified geographic layout. The impact EVs have on the energy system has been modelled using EnergyPLAN.

Key words: Electric vehicles, Demand side modelling, Agent-based modelling, Electrification of transport, EnergyPLAN, MATSim

\section{Introduction}

The transport sector represents a serious energy consumer in most energy systems across the EU and wider. In Croatia for example, the transport sector accounted for $32.8 \%$ of the final energy consumption in 2011 making it the second most energy demanding sector right after buildings with $43 \%$ [1]. In the last decade, the final energy demand of the transport sector has increased by approximately $70 \%$ due to a verity of reasons including economic growth and large investments into a modern highway infrastructure [2]. These numbers demonstrate a large potential for energy savings related to it especially if we consider the increase in transport demand and low efficiency of standard internal combustion engines (ICE).

As it has already been demonstrated in our previous work [2], a widespread electrification of the personal vehicle fleet could reduce the total final energy demand of the transport sector in Croatia by roughly $53 \%$ by the year 2050 when compared with a business as usual scenario. 
This represents a saving of $89 \mathrm{PJ}$ of energy. If a modal split from road and air to rail transport is taken into account as well, this savings could be increased to $59 \%$ or 99 PJ. Other authors have already demonstrated the benefits that electrification can have on an energy system when it comes to greenhouse gas emissions [3], [4] and [5] but in order to properly asses their impact on a system as a whole an hourly analysis has to be implemented. This is necessary to accommodate for the increase of peak demand of electricity and the potential for the utilization of batteries of parked electric vehicles (EVs) as energy storage mediums that can increase the possibility for the penetration of intermittent renewable energy sources (RES). The importance of the implementation of energy storage technologies on the penetration of intermittent RES has already been discussed by several authors [6], [7] and [8].

There are a variety of approaches already available for the forecast of the annual energy demand of the transportation sector such as the ones described in [9], [10] and [11] but, as it has been already stated earlier, an hourly distribution is needed here. To accommodate for this, agent based modelling (ABM) has been utilized in the case of this work. The ABM is a relatively young area of research applied widely so there are several definitions on basic concepts. Commonly, in ABM a system is modelled as a collection of autonomous decision-making entities called agents. These entities are placed into an environment and are able to autonomously react to changes in the environment. This definition in turn implies the agents' capability of sensing the environment and effecting (actuating) in order to interact with the environment and change it [12]. In other words the agent entities are able to capture information from the environment and percept the items of acquired information, and then act accordingly. In turn, these actions affect the environment; provoking further interactions from other entities. From the paradigm viewpoint, the $\mathrm{ABM}$ can also be seen as microscopic, i.e. per-entity modelling, as opposed to macroscopic modelling where the integral system is being modelled. Furthermore, the separation of agents and their environment indicates the inherent distributable characteristics of ABM. Several classifications of ABM consider the environment, e.g. its observability (i.e. whether an agent can gather the complete state of the environment), or whether the environment is deterministic or stochastic etc. The definition of agent considers a certain degree of autonomy. The agents may autonomously execute various behaviours appropriate for the system they represent (e.g. purchasing, consuming, and selling). An intelligent agent exhibits proactiveness, reactivity and social behaviour: it is able to act towards a certain goal, it can respond to changes in the environment and it is able to interact with other agents [13]. The intelligent agent research has largely emerged from artificial intelligence and one is able to build highly complex internal structures of the agents. Generally, ABM only requires the agents to place reasonable decisions about actions to be performed. Thus even with relatively simple agent definitions, ABM can deliver repetitive and competitive interactions between agents that result in complex behaviour patterns, and this is one of key advantages of ABM: it allows the emergence of complex behaviour patterns from relatively simple per-entity models. The ABMs have been successfully used in areas ranging from economics [14] and social sciences [15] to biology and diverse engineering areas [16]. In general, when the system being modelled is complex, modular and decentralized, changeable (i.e. not statically defined), and defined at the time of design, ABM is a well-fitted method of modelling.

The Goal of this work is to model the hourly distribution of the transport energy demand and utilize that data to analyse the impact personal EVs can have on the potential for the penetration of wind and PV power in an energy system. The agent based transportation system modelling tool MATSim [17] has been used to generate said distribution and the EnergyPLAN [18] advanced energy system analysis tool has been utilized to model Croatia's energy system and conduct the analysis. 


\section{Methodology}

The methodology of both the processes of obtaining the hourly energy demand curves for the road transport sector in MATSim and the energy system modelling in EnergyPLAN have been explained in this chapter.

\subsection{MATSim}

In order to properly analyze the interaction between personal EVs and the electricity grid an hourly distribution of the energy demand of personal road vehicles had to be created first. As stated above, the ABM is a well-fitting method for transport modeling: there are numerous agents whose decisions and behaviours, guided by their own intrinsic rules, that by interacting among them and with the environment impact the whole transportation system on a larger scale. Furthermore the transportation system conditions are not fixed. The application of ABM in the modelling of transport is diverse. In [19] the authors present a TAPAS system for simulation of transport chains, aimed towards transport-related policy and infrastructure measures. Similarly, in [20], the authors deliver insights in the use of agent-based modelling of transport logistics. This paper focuses on the simulation of urban transport, such as the study presented in [21], where the authors present a study on driver behaviour in congested streets of the city of Brisbane. Several tools for agent-based modelling of such urban traffic exist. NISAC FastTrans [22], developed at US Los Alamos National Laboratory is a discrete, event-based simulator designed to study the impacts of infrastructure components in crisis management and dynamic prioritization. MAINSIM [23], Multimodal Inner-city Simulation Tool is a tool developed in Goethe University in Frankfurt, Germany, aimed towards using map information directly. It is an actor-based simulation system. COS-SIM [24] is an open source tool for agent-based micro simulation of traffic flows, directed primarily towards tuning of the traffic control devices.

For the simulations in this paper, MATSim [17] was chosen as a simulation tool. The MATSIM model provides a framework to implement large-scale agent-based transport simulations. It is exceptionally modular: demand modeling, mobility simulations, replanning, controller module and analysis modules are provided. These modules can be used in combination or stand-alone. The MATSIM model is open-source, cross-platform and highly customizable, since its Java source code is freely available online. Thus MATSIM offers extensibility and allows the user to add additional functionalities to its modules and tailor the MATSIM for a particular problem.

A key feature of MATSIM is agent-based, multi-modal simulation of daily mobility behaviour. The MATSIM simulations utilize behaviour definition for single persons ("agents") to track and model the system behaviour on the whole. In the case of personal EV-based mobility, the aggregated behaviour is visible as an additional electricity demand and for this reason, along with the flexibility to include the EV-related specifics, MATSIM was selected as an appropriate tool for this paper.

The MATSIM simulation architecture [17] makes it particularly suitable for policy-making issues, and it has been successfully used in tasks such as assessing the emission impact due to household travelling [25] optimizing taxi service [26], determining policies on traffic planning [27], [28] etc.

\subsection{EnergyPLAN}

EnergyPLAN is a deterministic input output computer modelling tool that creates an annual analysis of an energy system on an hourly level. It requires a wide range of input data including the total annual demands and hourly demand curves for electricity, installed capacities and 
efficiencies of different types of energy producers (both renewable and non-renewable) and energy storage technologies, fuel mix, hourly distribution of energy production from intermittent sources like wind, solar and small hydro, the energy demands for different sectors including transport, hourly distribution of transport energy demand, vehicle to grid connection capacities, different regulation strategies and so on. The results of the model include energy balances, annual and hourly energy production by source and the critical excess of electricity production (CEEP) present in the system, fuel consumptions by fuel type, total cost of the system, $\mathrm{CO}_{2}$ emissions and so on.

EnergyPLAN is a well documented tool that specializes in the large scale integration of RES in energy systems [29] and [30], the optimal combination of RES [31] and the implementation of CHP units in energy systems [32]. It has already been used to recreate many different energy systems and devise numerous energy scenarios. For example, authors of [29] and [33] used the model to simulate different scenarios for the Macedonian energy system. In [32] and [34] EnergyPLAN has been used to model the Danish energy system and to analyze the potential for the integration of RES. The authors of [35] used both the EnergyPLAN and the $\mathrm{H}_{2} \mathrm{RES}$ [36] models to recreate the Croatian energy system and plan a 100\% energy independent scenario. EnergyPLAN has already been used to analysis of the impact of the transport sector, especially electric vehicles, on an energy system [37] and [38] in the past.

\section{Case study for Croatia}

The data gathering and processing and the development of the case study for Croatia using both MATSim and EnergyPLAN has been explained here.

\subsection{Hourly distribution of the transport energy demand}

In order to create an hourly energy demand curve for the Croatian road transport sector, more precisely personal vehicles, 4 individual distributions have been created for the cities of Zagreb, Rijeka, Split and Osijek. The sum of the four curves is used to represent the distribution for Croatia.

Inputs required by the MATSim are divided into the following categories:

- population: provides agent's identification (agent ID number), age, working municipality and longitudinal and lateral coordinates of home location

- activity plan: tells agent at which location (work, home, leisure, shopping) they should be at the specified time

- network: provides the detailed network for each city under the consideration and only the main roads outside the city limits

- facilities (optional): provides the longitudinal and lateral coordinates of non-home locations

The quality of the solution obtained by MATSim will be closer to reality if the input data resides on real-world observations. The best possible scenario is when each single agent represents one surveyed person, but this is highly impractical and impossible to get. Therefore, input data has to rely on survey conducted amog a limited number of surveyed people and set of data that is usually available in aggregated form. In order to reduce the number of input data and simplify the preparation of MATSim inputs, the following assumptions are used:

- the only activities are home and work

- leisure is assumed to be on the same locations as work

- there are no holidays within the year 
In order to find the population and activity plan inputs for the four biggest Croatian cities, the spatial distribution of home and work locations were estimated based on the socio-demographic data, available as aggregated values at the municipality level, building density per area and the official addresses of registered companies. Since the municipalities are too big to provide a sufficiently fine resolution of home and work locations, they are further divided into $200 \times 200$ $\mathrm{m}$ rectangular cells. At this resolution, the home and work locations can be found and overlaid over the road network, as presented in Figure 1 for the case study of Croatia.

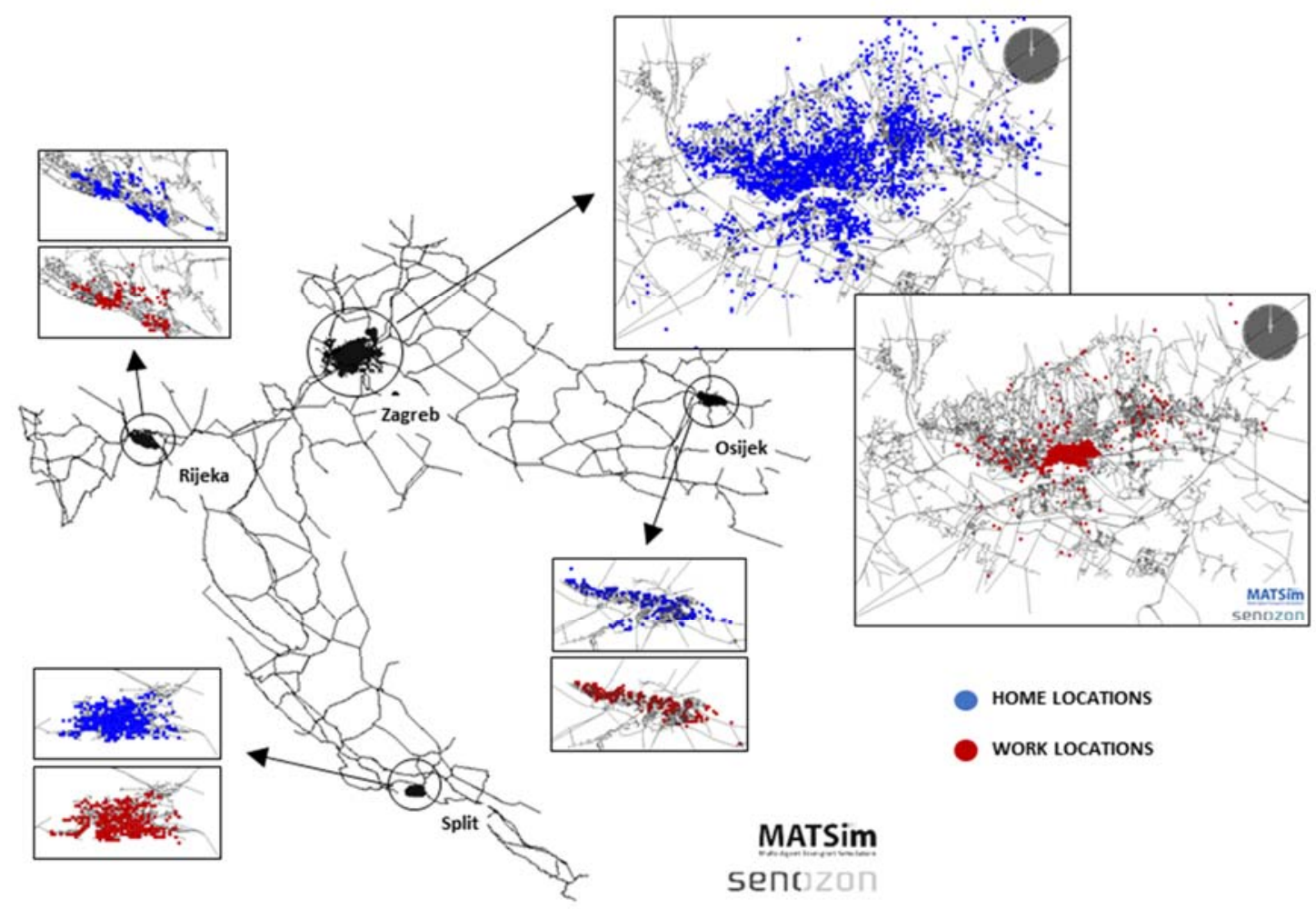

Figure 1 Network of Croatia's main roads coupled with the detailed road network in the four biggest cities overlaid with the facilities presenting agent's home and work activity locations.

Aggregated values for population and number of households for city municipalities can be found at the official web pages of each city [39], [40], [41] and [42] and boundaries of each city municipalities can be found as polygon data from Google Earth [43].

The buildings density per area is estimated from the percentage of each cell area covered by the building polygons, divided by the total area of the cell. Buildings polygon data are taken from the Geofabrik online database [44]. The addresses of companies are extracted from the Croatian Chamber of Economy (CoE) [45].

Table 1 Aggregated socio-demographic input data for Croatia's four biggest cities

\begin{tabular}{|c|c|c|c|c|}
\hline & Zagreb (ZG) & Split (ST) & Rijeka (RI) & Osijek (OS) \\
\hline $\begin{array}{r}\text { area limits in } \\
\text { WGS84 } \\
\text { coordinates } \\
\text { (estimation) }\end{array}$ & $\begin{array}{l}46.021 \mathrm{~N} 15.534 \mathrm{~W} \\
45.665 \mathrm{~S} 16.392 \mathrm{E}\end{array}$ & $\begin{array}{l}43.534 \mathrm{~N} 16.382 \mathrm{~W} \\
43.498 \mathrm{~S} 16.512 \mathrm{E}\end{array}$ & $\begin{array}{l}45.386 \mathrm{~N} 14.3348 \mathrm{~W} \\
45.307 \mathrm{~S} 14.520 \mathrm{E}\end{array}$ & $\begin{array}{l}45.584 \mathrm{~N} 18.596 \mathrm{~W} \\
45.525 \mathrm{~S} 18.776 \mathrm{E}\end{array}$ \\
\hline
\end{tabular}




\begin{tabular}{|r|l|l|l|l|}
\hline $\begin{array}{r}\text { No. of } \\
\text { municipalities }\end{array}$ & $17[39]$ & $27[40]$ & $34[41]$ & $15[42]$ \\
\hline $\begin{array}{r}\text { No. of employed } \\
(2011 \text { census) [46] }\end{array}$ & 322.256 & 63.561 & 50.494 & 38.786 \\
\hline $\begin{array}{r}\% \text { of employed } \\
\text { driving a car }\end{array}$ & $62[47] 77[48]$ & $62^{\text {(est.) }}$ & $62^{\text {(est.) }}$ & $62^{\text {(est.) }}$ \\
\hline $\begin{array}{r}\text { Estimated number } \\
\text { of agents travelling } \\
\text { by car }\end{array}$ & 199.798 & 39.407 & 31.306 & 24.047 \\
\hline
\end{tabular}

Total number of employees is provided by the Croatian Bureau of Statistics [46]. Total number of agents for each city municipality is estimated as a total number of employees multiplied by a percentage of employees having personal vehicles as a mode of transport [47].

Activity plan for each agent should provide the coordinates of each activity and their time series during the day. Activities are different for the work day or weekend. In this work, the only activities are home and work. Home location for each agent is found among the available cells taking into account the probability of the building density. An example for the city of Zagreb is given in Figure 2 with a resolution of 200 by $200 \mathrm{~m}$.

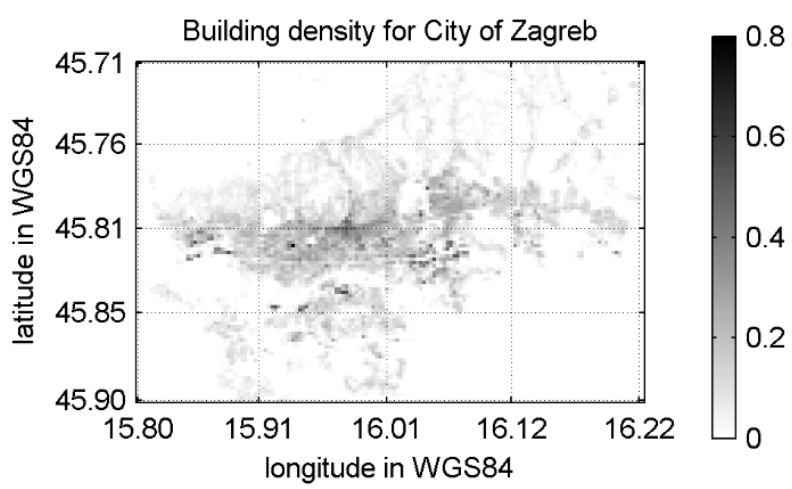

Figure 2 Distribution of the building densities in the city of Zagreb

Finding the work location for each agent is divided into two steps. In the first step, the municipality of the work location is found from the solution of the origin-destination (O-D) matrix, whose rows represent probabilites of work municipalities and it's sum of column values corresponds to toal number of registered businesses for each municipality, normalized by the total number of businesses. The O-D matrix is solved by the iterative proportional fitting (IPF) algorithm. The penalty function for the IPF procedure is the interpolation between the O-D matrix distance values between municipalities and the daily driven kilometres from the input survey [48], Fig.3. The survey has been conducted by the Energy Institute Hrvoje Požar for the city of Zagreb on a sample of 361 people. In the second step, the exact cell of the work location cell is found from the building density within the target municipality, by following the same procedure as in the case of finding the home locations. 


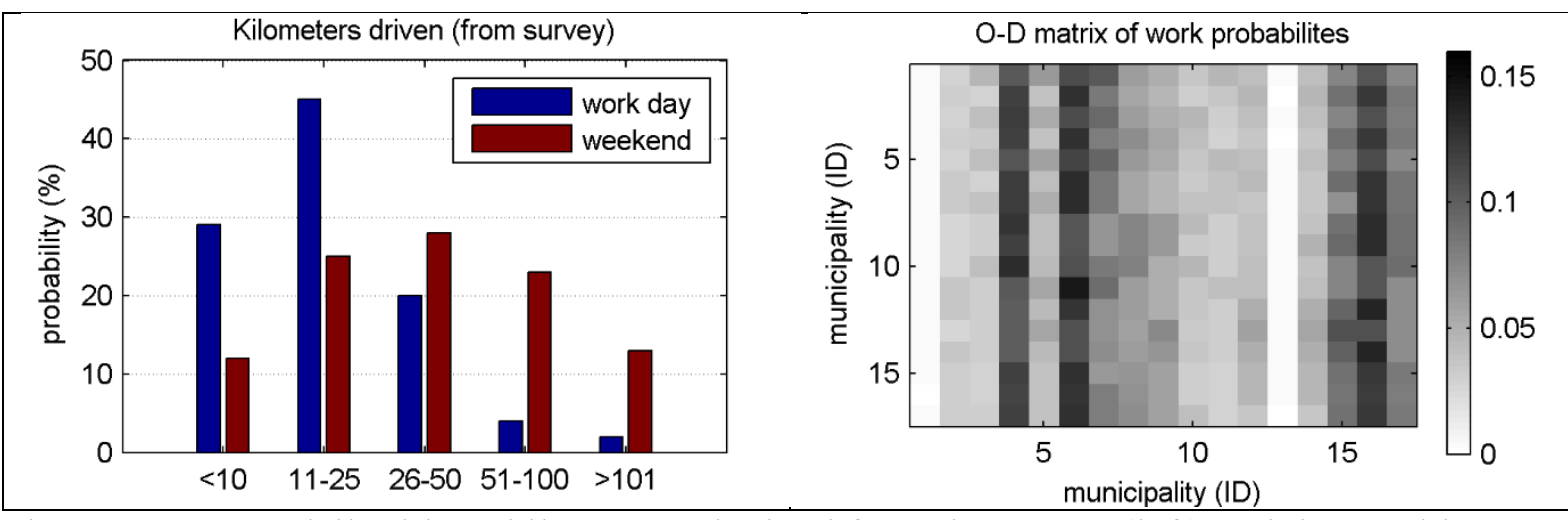

Figure 3 average daily driven kilometres obtained from the survey (left) and the resulting O-D matrix of the probabilities for work municipalities for the City of Zagreb (right)

From Figure 3 three municipalities can be recognized as municipalities with the most registered businesses, which follows directly from the CoE inputs.

Time series are constructed from the assumption that departures from the home, work and leisure/shopping locations follow a normal distribution. Typical distributions for the work day and the weekend are presented in Figure 4.

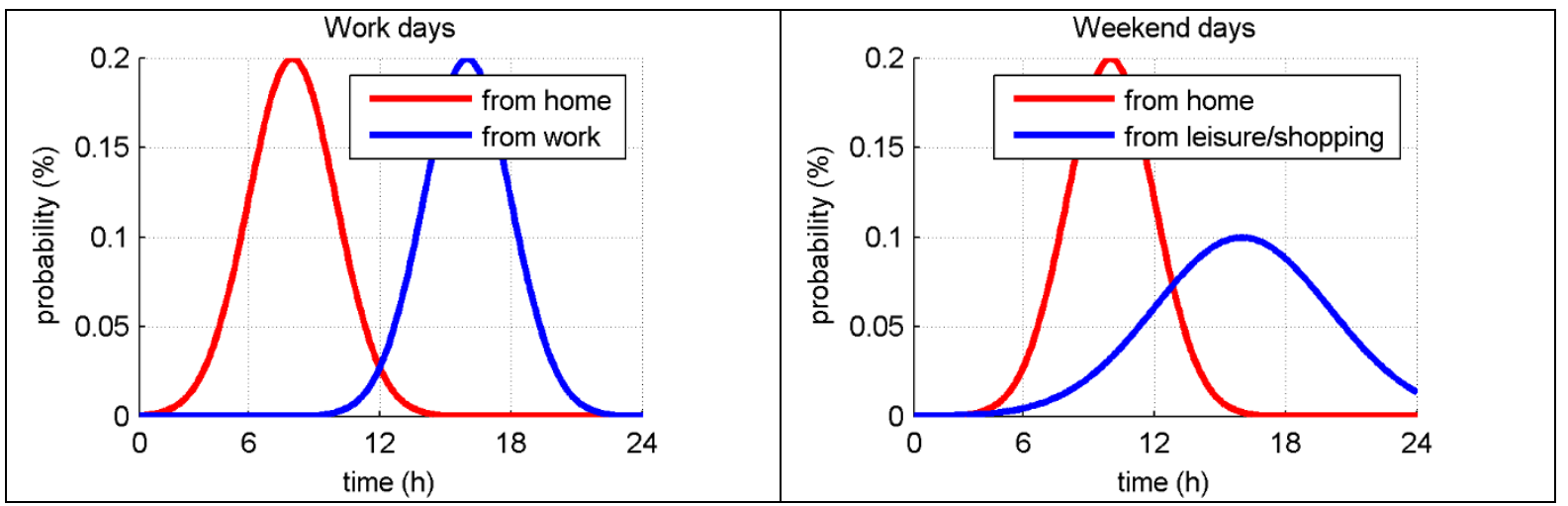

Figure 4 Time series probabilities for activities home, work and leisure/shopping for work day (left) and weekend (right)

MATSim utilizes the time series, O-D matrix and the developed transport network to generate the agent's behaviour and with that the hourly distribution curve. The difference between the input time series and output distribution is presented in Figure 5.

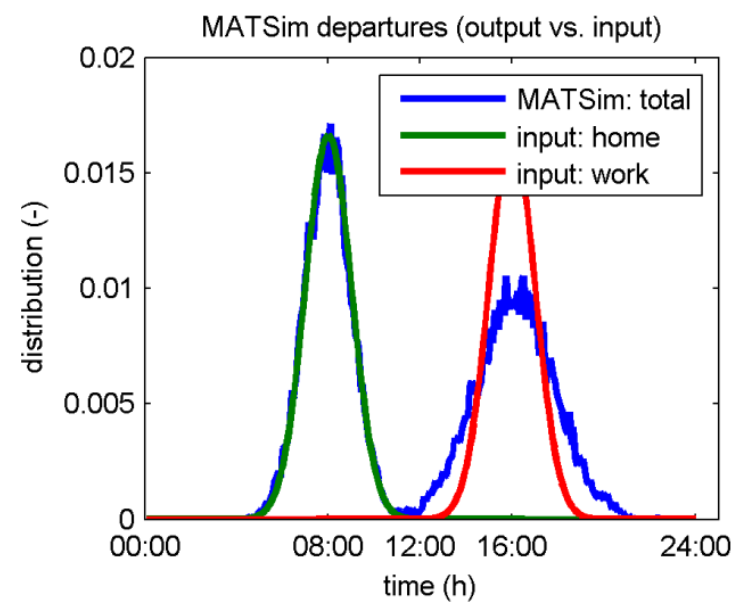

Figure 5 Difference between the input time series and output distribution 
The network is extracted from the OpenStreetMap data, region Europe, sub-region Croatia, downloaded from the Geofabrik web server [44].

\subsection{Modelling of Croatia's energy system}

In order to analyse the impact EVs have on the grid a reference model of Croatia's energy system has been created in EnergyPLAN. As it has already been mentioned, EnergyPLAN requires a wide variety of inputs. The fuel mix of the large thermal power plants as well as the energy use of the individual sectors has been adopted form the International Energy Agencies (IEA) web site [49]. The hourly electricity load has been taken from the web site of the European Network of Transmission System Operators for Electricity [50]. Meteorological data including global insolation and wind speeds have been taken from Meteonorm [51] and used to calculate the hourly production from wind power and PV. The obtained annual figures were then compared with the data available on the IEA website [49]. These data is presented below in Table 2. The installed capacities of the installed power plants have been taken from [1] and [52] and the statistical information related to the number of personal vehicles from [53]. A minimal grid stabilization share, the minimum production of electricity from power plants capable of providing ancillary services in relation to the total production of electricity, has been set to $30 \%$ in all scenarios. The minimal capacity of thermal power plants (PP min) of $42 \%$ has been assumed. The technical regulation strategy number 2 has been used "Balancing both heat and power demands". The impact of different optimisation criteria on energy systems has been discussed in [54] in great detail. The $\mathrm{CO}_{2}$ content of the different fuels has been taken from [33].

In order to validate the created scenario, several parameters calculated by EnergyPLAN have been compared to the ones listed on the IEA web site. Table 2 presents the comparison of the results obtained from EnergyPLAN and the data from the IEA [49]. As the table shows, there is a difference of $3.5 \%$ between the calculated $\mathrm{CO}_{2}$ emissions and the ones listed by the IEA. This is due to the emission factors that the IEA uses. The electricity production from fossil fuels, hydro and renewables is almost identical for both cases. The great difference between the electricity produced from nuclear energy and the import and export of electricity is due to the way the IEA regards the nuclear power plant in Krško, Slovenia. It is partially owned by Croatia and partially by Slovenia but since it is located outside of Croatia's borders, the electricity it produces and distributes to Croatia is regarded as import. If we add up the electricity generated by it with the electricity import and export, the resulting values are almost identical.

Table 2 Validation of the EnergyPLAN model

\begin{tabular}{|l|l|l|}
\hline & EnergyPLAN & Iea.org [49] \\
\hline Total $\mathrm{CO}_{2}$ emissions & $18.11 \mathrm{Mt}$ & $18.77 \mathrm{Mt}$ \\
\hline Electricity produced from fossil fuels & $6.00 \mathrm{TWh}$ & $6.01 \mathrm{TWh}$ \\
\hline Electricity produced from hydro energy & $4.63 \mathrm{TWh}$ & $4.62 \mathrm{TWh}$ \\
\hline Electricity produced from renewables & $0.20 \mathrm{TWh}$ & $0.201 \mathrm{TWh}$ \\
\hline Electricity produced from nuclear & $2.97 \mathrm{TWh}$ & $0 \mathrm{TWh}$ \\
\hline Electricity import & $4.73 \mathrm{TWh}$ & $8.730 \mathrm{TWh}$ \\
\hline Electricity export & $0.01 \mathrm{TWh}$ & $1.033 \mathrm{TWh}$ \\
\hline Import - export + nuclear & $7.69 \mathrm{TWh}$ & $7.697 \mathrm{TWh}$ \\
\hline
\end{tabular}




\section{Results}

\subsection{MATSim results}

Results obtained from MATSim are time series of kilometres that vehicles travel for each day of the week for each of the four cities taken into consideration, Figure 6 .

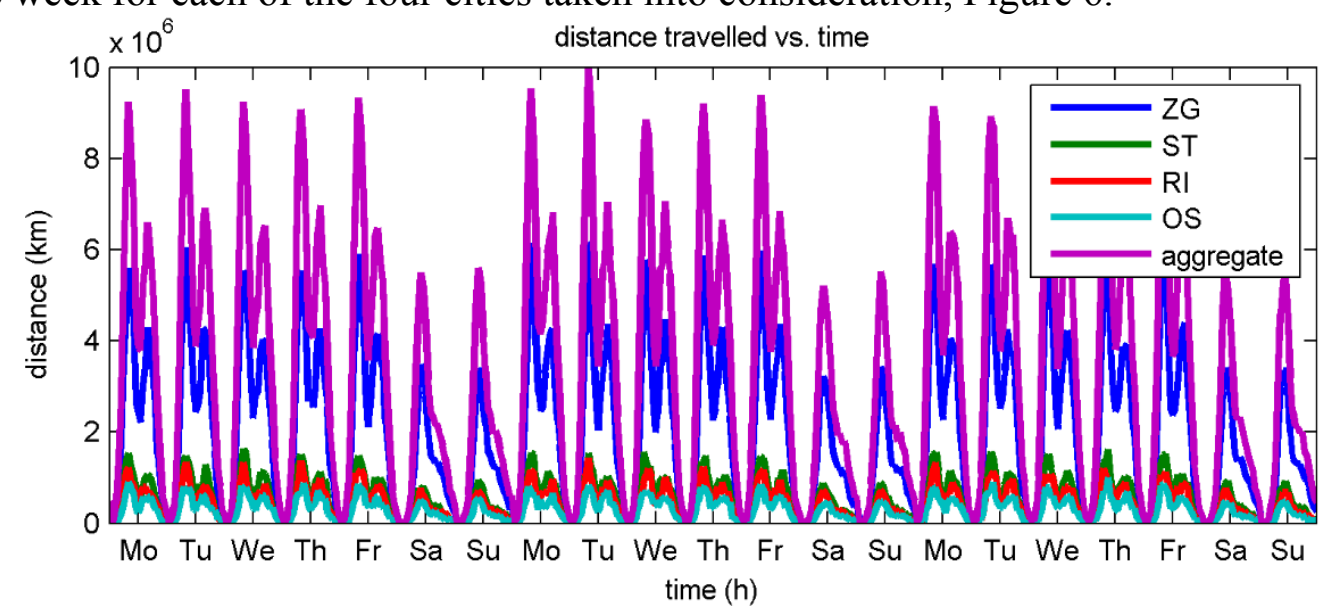

Figure 6 Output from MATSim: time series of kilometres driven for three weeks

The time series of travelled distance is strongly following the time series of prescribed activities. The city of Zagreb is the most dominant in the aggregated value.

\subsection{EnergyPLAN results}

In order to analyze the impact of EVs on Croatia's energy system, 12 scenarios have been devised. The first 6 scenarios analyse the potential for the penetration of wind power for a baseline scenario with EVs and 5 scenarios with EV penetration of $10 \%, 20 \%, 30 \%, 40 \%$ and $50 \%$. The second set of 6 scenarios analyse the same scenarios but for PV penetration. The wind and PV penetrations are varied from $0 \%$ to $50 \%$ of the total electricity demand (excluding EVs), meaning that the production of electricity from wind or PV equals $0 \%$ to $50 \%$ of the total electricity demand excluding EVs, with a step of 5\%. 

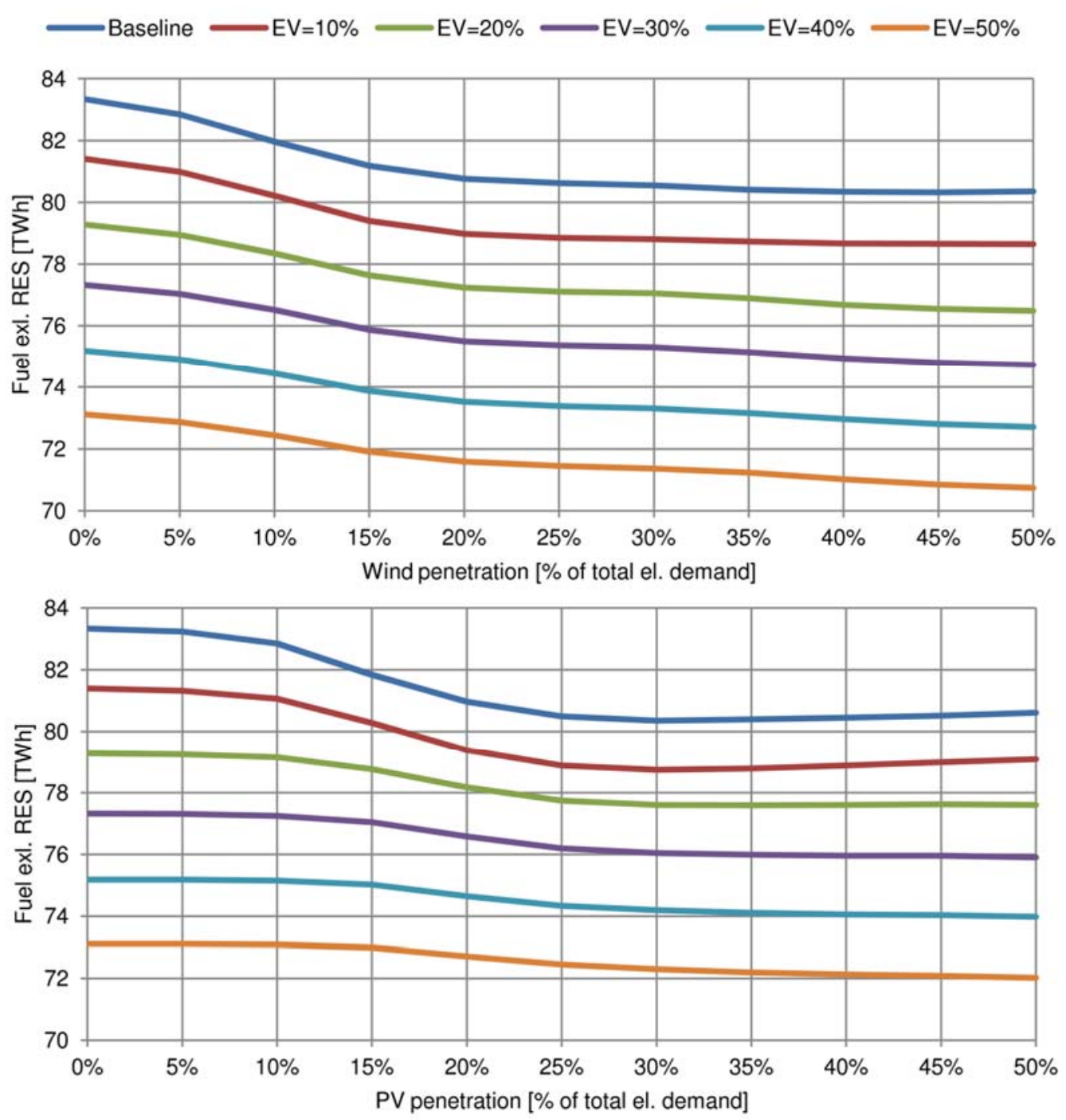

Figure 7 Fuel consumption excluding RES for scenarios with wind (top) and PV (bottom)

Figure 7 presents the total fuel consumption excluding RES for the six scenarios with wind (top figure) and PV (bottom figure). As it is expected, the scenarios with a higher penetration of RES have lower fuel consumption and the increase in the penetration of EVs also has a positive effect on its reduction. This is primarily due to the fact that EVs are considerably more efficient, upwards of $300 \%$ more in some cases, but also because the increase of their penetration presents a storage capacity for excess electricity and thus can increase the potential for the penetration of intermittent RES like wind and PV. In this work the average efficiency of vehicles with ICEs was presumed to be $1.5 \mathrm{~km} / \mathrm{kWh}$ and for EVs $5 \mathrm{~km} / \mathrm{kWh}$. A $50 \%$ share of EVs can reduce the total fuel consumption of the whole system (including all sectors not just energy and transport) from the base value of $83.34 \mathrm{TWh}$ to $73.11 \mathrm{TWh}$ which is a difference of $10.23 \mathrm{TWh}$ or $12.3 \%$. Higher penetrations of RES do not have a significant impact on the reduction of fuel consumption; in the baseline scenario a $50 \%$ penetration of wind power reduces the total fuel consumption from the base value of $83.34 \mathrm{TWh}$ to $80.35 \mathrm{TWh}$, a difference of merely $3.5 \%$. The results are fairly similar for PV with a reduction of $3.26 \%$. This is true because of the high dependence on imported electricity which doesn't register as fuel consumption. When such import is replaced with electricity from RES, fuel consumption of the system stays almost unchanged. 

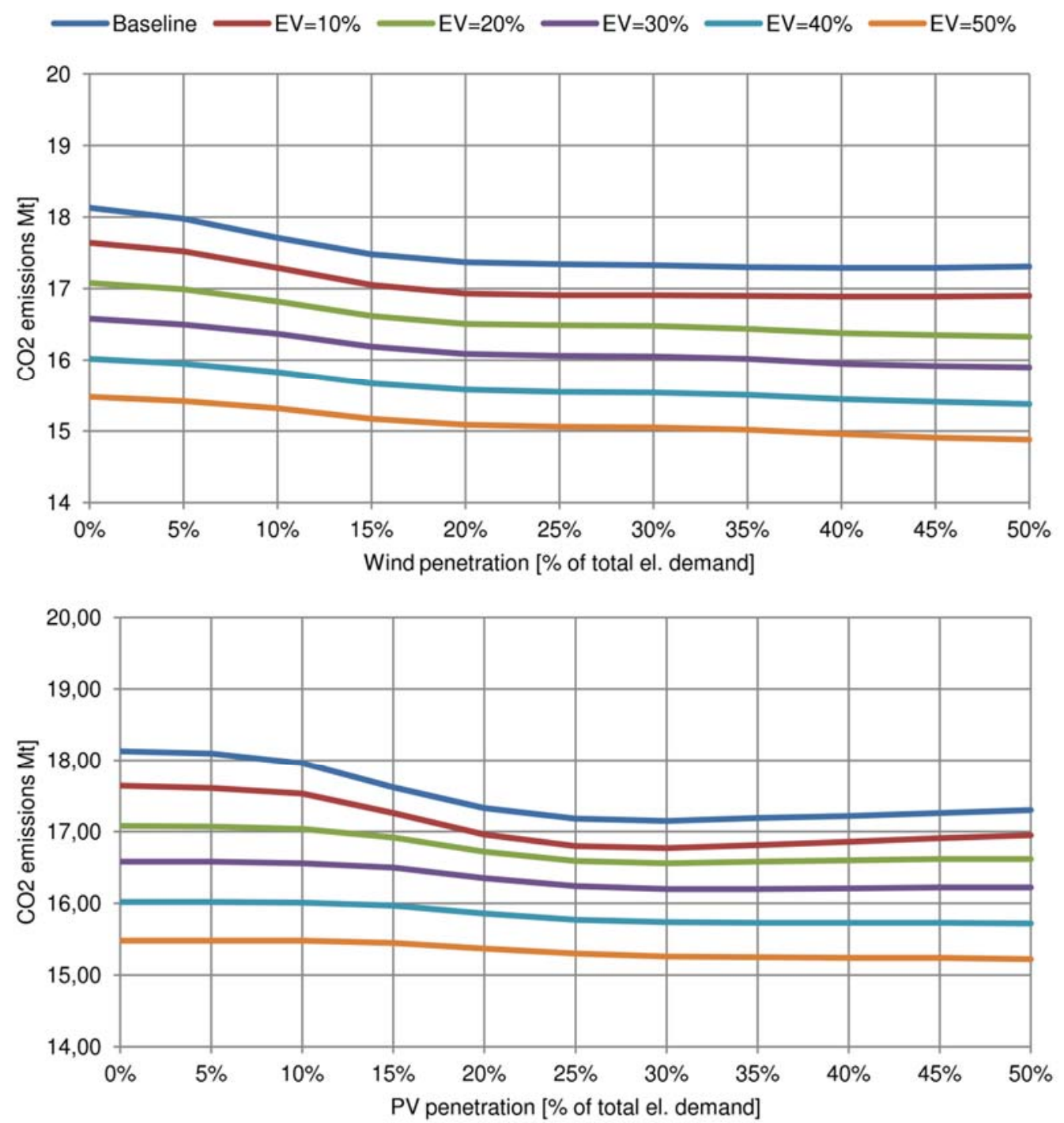

Figure $8 \mathrm{CO}_{2}$ emissions for scenarios with wind (top) and PV (bottom)

Figure 8 presents the annual $\mathrm{CO}_{2}$ emissions for the six scenarios with wind (top figure) and PV (bottom figure). The data on the figures closely follow the trend of the fuel consumption presented in Figure 7, which is to be expected A 50\% share of EVs has reduced the total annual $\mathrm{CO}_{2}$ emissions of the whole energy system, again including all sectors, from the initial value of 18.13 Mt to $15.48 \mathrm{Mt}$, a reduction of $14.6 \%$ in the presented scenarios. Again, similar to the results presented in the previous figure, the penetration of RES doesn't affect the $\mathrm{CO}_{2}$ emissions significantly for the same reason it doesn't influence fuel consumption. Both for a wind and for a PV penetration of $50 \%$ the total $\mathrm{CO}_{2}$ emissions are reduced to $17.3 \mathrm{Mt}$, a reduction of $4.6 \%$. 

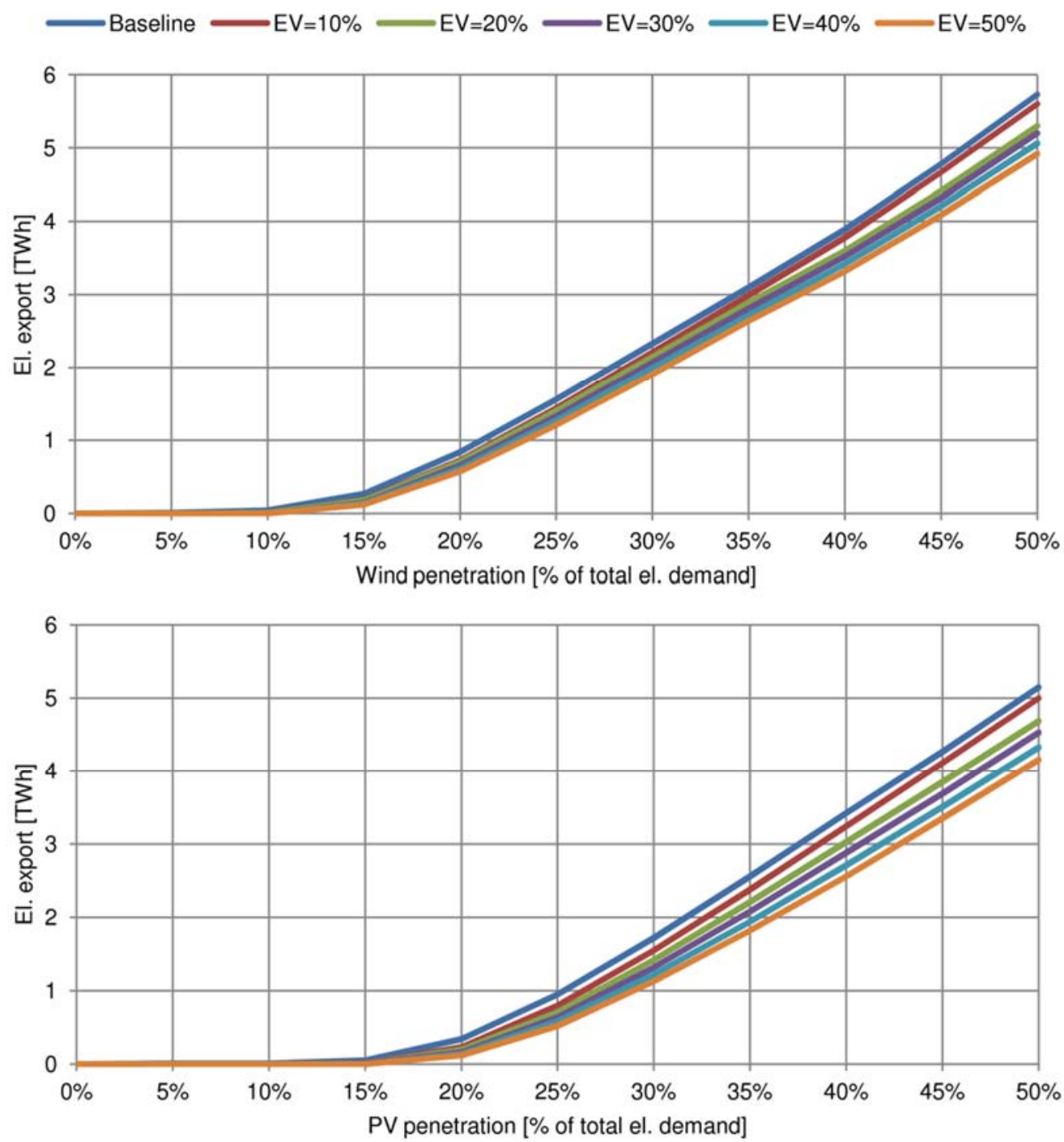

Figure 9 Export of electricity for scenarios with wind (top) and PV (bottom)

Figure 9 presents the total annual export of electricity, again for the scenarios with wind (top figure) and PV (bottom figure). It can be observed from the figures that a penetration of wind higher than $10 \%$ or PV higher than $15 \%$ will force the system to export some electricity. In the case of the scenarios that include wind power, its penetration of $15 \%$ with no EVs resulted in the export of $0.27 \mathrm{TWh}$, or $0.12 \mathrm{TWh}$ for an EV share of $50 \%$. In the case of a $50 \%$ wind power penetration the figures go up to $5.73 \mathrm{TWh}$ with no EVs and $4.92 \mathrm{TWh}$ with an EV share of $50 \%$. The results are similar for the scenarios with PV, although the export is somewhat reduced. For the case of a PV penetration of $15 \%$ and no EVs, the electricity export equals 0.05 TWh. There is no export present in the same case but with a $50 \%$ share of EVs. For a PV penetration of $50 \%$ and no EVs, the electricity export equals $5.15 \mathrm{TWh}$ and $4.16 \mathrm{TWh}$ for an EV share of $50 \%$. The difference in the exported electricity for a scenario with $50 \%$ wind penetration with no EVs and with $50 \%$ EVs is $0.81 \mathrm{TWh}$ or roughly $4.4 \%$ of the total electricity demand, excluding EVs, of Croatia in the year 2011. In the case of PV the same difference is 0.99 TWh or roughly $5.3 \%$ of the total electricity demand excluding EVs. 

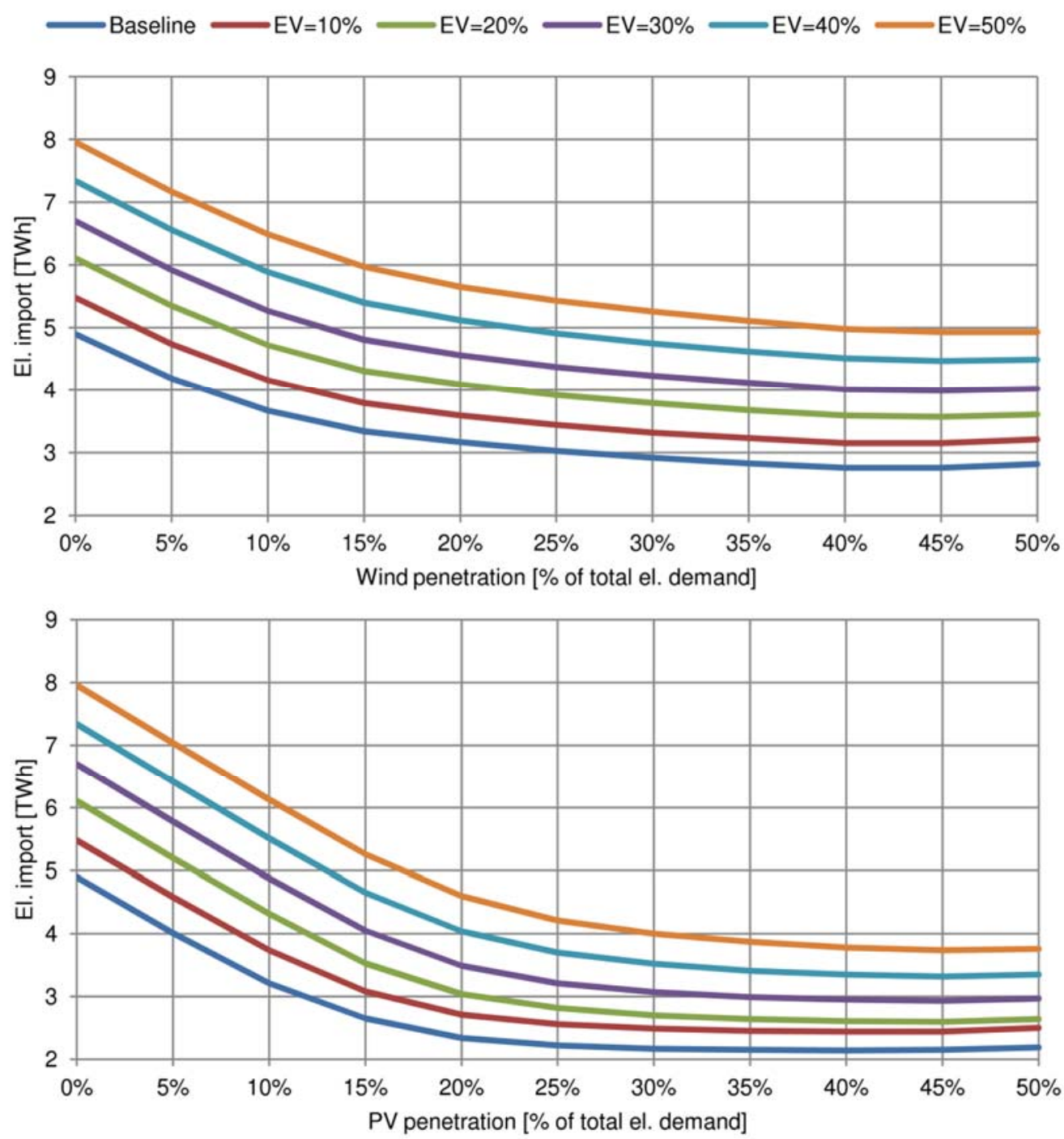

Figure 10 Import of electricity for scenarios with wind (top) and PV (bottom)

Figure 10 presents the total annual import of electricity for the scenarios with wind power (top figure) and PV (bottom figure). Since Croatia already imports a significant amount of electricity every year, $8.73 \mathrm{TWh}$ in the year 2011 which is equal to $47 \%$ of the total electricity demand of that year [49], the additional demand posed by the EVs would naturally increase these values. This is evident from the presented figures. A $50 \%$ share of EVs increased the necessary import of electricity from the base value of 4.9 to $7.96 \mathrm{TWh}$.

\section{Sensitivity analysis}

In order to determine the impact that the detailed analysis of the transport demand has on the energy planning results a sensitivity analysis has been conducted comparing the hourly distribution obtained using MATSim, presented by Figure 6, and a constant distribution. CEEP has been compared for the two curves for three different penetrations of EVs $(10,30$ and $50 \%)$ and for a wind power penetration ranging from $30 \%$ to $50 \%$ with a step of $5 \%$. Wind power penetrations below 30\% are not analysed since CEEP is always 0 for these case in the created scenarios. The results of the sensitivity analysis have been presented in Table 3 . 
Table 3 Results of the sensitivity analysis

\begin{tabular}{|r|r|r|r|r|r|r|}
\hline & \multicolumn{2}{|c|}{$\mathrm{EV}=10 \%$} & \multicolumn{2}{c|}{$\mathrm{EV}=30 \%$} & \multicolumn{2}{c|}{$\mathrm{EV}=50 \%$} \\
\hline Wind & MATSim & Constant & MATSim & Constant & MATSim & Constant \\
\hline $30 \%$ & $0 \%$ & $0 \%$ & $0 \%$ & $0 \%$ & $0 \%$ & $0 \%$ \\
\hline $35 \%$ & $8 \%$ & $8 \%$ & $2 \%$ & $2 \%$ & $0 \%$ & $1 \%$ \\
\hline $40 \%$ & $33 \%$ & $33 \%$ & $15 \%$ & $17 \%$ & $9 \%$ & $11 \%$ \\
\hline $45 \%$ & $77 \%$ & $78 \%$ & $49 \%$ & $53 \%$ & $36 \%$ & $42 \%$ \\
\hline $50 \%$ & $132 \%$ & $133 \%$ & $98 \%$ & $104 \%$ & $81 \%$ & $90 \%$ \\
\hline
\end{tabular}

As the results in Table 3 demonstrate, the difference for a low penetration of EVs is very small between the generated distribution curve and a constant line. For an EV penetration of $10 \%$ the difference between the two distributions is only about $1 \%$. The difference becomes much more significant at $30 \%$ and $50 \%$ EV penetration. For $30 \%$ the difference varies from $6 \%$ to $12 \%$ and for $50 \%$ it varies from $10 \%$ to $18 \%$.

\section{Conclusion}

Agent based modelling can be a strong tool for the modelling of the hourly distribution of energy demand of the transport sector. As it has already been stated, the quality of the results of the modelling will be highly dependent on the quality of the inputs.

The obtained hourly energy demand curves for the Croatian road transport sector has been used in the EnergyPLAN tool to analyse the impact of electric vehicles on Croatia's energy system and the potential for the increase of the penetration of wind power and PV. The results have shown that the electrification of the road transport sector can help reduce the fuel consumption by $12.3 \%$ and $\mathrm{CO}_{2}$ emissions by $14.6 \%$ for the case of no renewables and a $50 \%$ share of electric vehicles. These numbers are even greater when higher penetrations of renewables are taken into account. A conducted sensitivity analysis has shown that the hourly distribution of the EV demand can have a strong influence on the obtained results at high levels of EV and intermittent RES penetration. In our case the difference in CEEP was up to $18 \%$ between the distribution generated using MATSim and a constant demand.

Future work related to this paper will include the development and utilization of a detailed survey aimed at the energy consumption of personal transport and the validation and further refinement of the obtained distributions.

\section{Acknowledgment}

The authors are grateful for support by the Croatian Science Foundation for financing this work through the project iRESEV (no. 09/128).

\section{Bibliography}

[1] B. Vuk, S. Vukman, M. Karan, R. Fabek, S. Živković, M. Maričević, T. Baričević, S. Antešević, J. M. Abramović, N. Karadža, T. Borković, V. Krstulović and Ž. Jurić, "Annual Energy Report: Energy in Croatia 2011," Energy Institute Hrvoje Požar, Zagreb, 2012. 
[2] T. Pukšec, G. Krajačić, Z. Lulić, B. V. Mathiesen and N. Duić, "Forecasting long-term energy demand of Croatian transport sector," Energy, vol. 57, pp. 169-176, 2013.

[3] M. Sorrentino, G. Rizzo and L. Sorrentino, "A study aimed at assessing the potential impact of vehicle electrification on grid infrastructure and road-traffic green house emissions," Applied Energy, vol. 120, pp. 31-40, 2014.

[4] M. Sugiyama, "Climate change mitigation and electrification," Energy Policy, vol. 44, pp. 464-468, 2012.

[5] O. Bahn, M. Marcy, K. Vaillancourt and J.-P. Waaub, "Electrification of the Canadian road transportation sector: A 2050 outlook with TIMES-Canada," Energy Policy, vol. 62, pp. 593-606, 2013.

[6] R. Segurado, G. Krajačić, N. Duić and L. Alves, "Increasing the penetration of renewable energy resources in S. Vicente, Cape Verde," Applied Energy, vol. 88, pp. 466-472, 2011.

[7] G. Krajačić, N. Duić, Z. Zmijarević, B. V. Mathiesen, A. A. Vučinić and M. d. G. Carvalho, "Planning for a $100 \%$ independent energy system based on smart energy storage for integration of renewables and CO2 emissions reduction," Applied Thermal Engineering, vol. 31, pp. 2073-2083, 2011.

[8] D. Connolly, H. Lund, B. Mathiesen, E. Pican and M. Leahy, "The technical and economic implications of integrating fluctuating renewable energy using energy storage," Renewable Energy, vol. 43, pp. 47-60, 2013.

[9] Z. WooGeem, "Transport energy demand modeling of South Korea usinga rtificial neural network," Energy Policy, vol. 39, p. 4644-4650, 2011.

[10] M. Zhang, H. Mu, G. Li and Y. Ning, "Forecasting the transport energy demand based on PLSR method in China," Energy, vol. 34, p. 1396-1400, 2009.

[11] J. Anable, C. Brand, M. Tran and N. Eyre, "Modelling transport energy demand: A sociotechnical approach," Energy Policy, vol. 41, pp. 125-138, 2012.

[12] M. Wooldridge, An Introduction to MultiAgent Systems, London: John Wiley \& Sons, 2009.

[13] S. Russell and P. Norvig, Artificial Intelligence: A Modern Approach, New Jersey: Upper Saddle River, 2009.

[14] L. Tesfatsion and K. Judd, "Agent-Based Computational Economics: A Constructive Approach to Economic Theory," in Handbook of Computational Economics, 2006, p. 831-880.

[15] R. Axelrod and L. Tesfatsion, "On-Line Guide for Newcomers to Agent-Based Modeling in the Social Sciences," 2014. [Online]. Available: www2.econ.iastate.edu/tesfatsi/abmread.htm. [Accessed 02 December 2014].

[16] M. Dorigo, “Swarm Intelligence," 2014. [Online]. Available: http://www.springer.com/computer/ai/journal/11721.

[17] MATSim, “Agent-Based Transport Simulations|MATSim," 2012. [Online]. Available: http://www.matsim.org/. [Accessed 16 November 2013].

[18] EnergyPLAN, "EnergyPLAN|Advanced Energy Systems Analysis Tool," Department of Development and Planning, Aalborg University, [Online]. Available: http://www.energyplan.eu/. [Accessed 21 October 2013].

[19] J. Holmgren, P. Davidsson, J. A. Persson and L. Ramstedt, "TAPAS: A multi-agent-based model for simulation of transport chains," Simulation Modelling Practice and Theory, vol. 23, pp. 1-18, 2012. 
[20] P. Davidsson, L. Henesey, L. Ramstedt, J. Törnquist and F. Wernstedt, “An analysis of agent-based approaches to transport logistics," Transportation Research Part C: Emerging Technologies, vol. 13, no. 4, p. 255-271, 2005.

[21] H. Dia, "An agent-based approach to modelling driver route choice behaviour under the influence of real-time information," Transportation Research Part C: Emerging Technologies, vol. 10, no. 5-6, pp. 331-349, 2002.

[22] LANL, "FastTrans: Transportation Simulator," 2014. [Online]. Available: http://www.lanl.gov/programs/nisac/fasttrans.shtml. [Accessed 8 January 2014].

[23] MAINSIM, "MAINSIM - MultiModal Intercity Street Traffic Simulator," [Online]. Available: http://www.mainsim.de/?lang=en. [Accessed 8 January 2014].

[24] COS-SIM. [Online]. Available: https://code.google.com/p/cos-sim/. [Accessed 6 January 2014].

[25] M. Hatzopoulou, J. Y. Hao and E. J. Miller, "Simulating the impacts of household travel on greenhouse gas emissions, urban air quality, and population exposure," Transportation, vol. 38, p. 871-887, 2011.

[26] M. Maciejewski and K. Nagel, "Simulation and optimization of taxi services in MATSim,” in VSP Working Paper, Berlin, 2013.

[27] J. W. Joubert, P. J. Fourie and K. W. Axhausen, "Large-Scale Agent-Based Combined Traffic Simulation of Private Cars and Commercial Vehicles," Transportation Research Record, vol. 2168, pp. 24-32, 2010.

[28] W. Gao, M. Balmer and E. J. Miller, "Comparisons between MATSim and EMME/2 on the Greater Toronto and Hamilton Area Network," Journal of the Transportation Research Board, vol. 2197, pp. 118-128, 2010.

[29] B. Ćosić, G. Krajačić and N. Duić, “A 100\% renewable energy system in the year 2050: The case of Macedonia," Energy, vol. 48, no. 1, pp. 80-87, 2012.

[30] W. Liu, H. Lund and B. V. Mathiesen, "Large-scale integration of wind power into the existing Chinese energy system,” Energy, vol. 36, no. 8, p. 4753-4760, 2011.

[31] H. Lund, "Large-scale integration of optimal combinations of PV, wind and wave power into the electricity supply," Renewable Energy, no. 31, pp. 503-515, 2006.

[32] H. Lund and E. Munster, "Modelling of energy systems with a high percentage of CHP and wind power," Renewable Energy, vol. 28, no. 14, pp. 2197-2193, 2003.

[33] B. Ćosić, N. Markovska, G. Krajačić, V. Taseska and N. Duić, "Environmental and economic aspects of higher RES penetration into Macedonian power system," Applied Thermal Engineering, vol. 43, pp. 158-162, 2012.

[34] H. Lund and B. V. Mathiesen, "Energy system analysis of 100\% renewable energy systems - The case of Denmark in years 2030 and 2050," Energy, vol. 34, no. 5, pp. 524$531,2009$.

[35] G. Krajačić, N. Duić, Z. Zmijarević, B. V. Mathiesen, A. A. Vučinić and M. G. Carvalho, "Planning for a $100 \%$ independent energy system based on smart energy storage for integration of renewables and CO2 emissions reduction," Applied Thermal Engineerin, vol. 31, no. 13, pp. 2073-2083, 2011.

[36] "H2RES Model," [Online]. Available: http://powerlab.fsb.hr/h2res/. [Accessed 12 February 12].

[37] H. Lund and W. Kempton, "Integration of renewable energy into the transport and electricity sectors through V2G," Energy Policy, vol. 36, no. 9, p. 3578-3587, 2008. 
[38] M. Munster and H. Lund, "Use of waste for heat, electricity and transport - Challenges when performing energy system analysis," Energy, no. 34, pp. 636-644, 2009.

[39] "City of Zagreb official pages," [Online]. Available: http://www.zagreb.hr/default.aspx?id=12915. [Accessed 0105 2014].

[40] "City of Split official pages," [Online]. Available: http://www.split.hr/Default.aspx?sec=376. [Accessed 0105 2014].

[41] "City of Rijeka official pages," [Online]. Available: http://www.rijeka.hr/mo. [Accessed $01052014]$.

[42] "City of Osijek official pages," [Online]. Available: http://www.osijek.hr/index.php/cro/Mjesna-samouprava/Mjesni-odbori-i-gradskecetvrti. [Accessed 0105 2014].

[43] "Google Earth official," [Online]. Available: http://www.google.com/earth/. [Accessed 0105 2014].

[44] "Geofabrik OpenStreetMap data (Europe)," [Online]. Available: http://download.geofabrik.de/europe.html. [Accessed 0105 2014].

[45] "Croatian Chamber of Economy official pages," [Online]. Available: http://www.hgk.hr/. [Accessed 0205 2014].

[46] "Croatian Bureau of Statistics," [Online]. Available: http://www.dzs.hr/. [Accessed 0105 2013].

[47] F. Foundation for the Automobile and Society, "The Automobile and Society".

[48] "Strategija razvoja energetske infrastrukture za napajanje električnih vozila na području Grada Zagreba,” EIHP, Zagreb, 2013.

[49] IEA, "International Energy Agency," 2013. [Online]. Available: www.iea.org. [Accessed 8 January 2013].

[50] ENTSO-E, "European Network of Transmission System Operators for Electricity," 2013. [Online]. Available: https://www.entsoe.eu/. [Accessed 16 December 2013].

[51] meteonorm, "Meteonorm," 2013. [Online]. Available: meteonorm.com. [Accessed 6 January 2014].

[52] HEP, "HEP Group," [Online]. Available: http://www.hep.hr/hep/publikacije/godisnje/2011godisnje.pdf. [Accessed 16 December 2013].

[53] DZS, "Statistical Yearbook of the Republic of Croatia," Croatian Bureau of Statistics, Zagreb, 2012.

[54] P. A. Østergaard, "Reviewing optimisation criteria for energy systems analyses of renewable energy integration," Energy, vol. 34, no. 9, p. 1236-1245, 2009. 